\title{
Naar een integraal alcoholbeleid in België
}

\author{
Ruben Kramer · Else De Donder · Martin de Duve · Tina Van Havere · Marijs Geirnaert · Frieda Matthys · \\ Tom Decorte
}

Published online: 12 June 2020

(C) The Author(s) 2020

\begin{abstract}
Samenvatting De alomtegenwoordigheid en sociale aanvaarding van alcohol in België verbloemt in vele gevallen de schadelijke gevolgen die alcohol heeft. Om die gevolgen te reduceren, is er de afgelopen jaar veel onderzoek gedaan naar de effectiviteit van mogelijke overheidsmaatregelen. Onder andere de Wereldgezondheidsorganisatie adviseert landen over effectieve beleidsmaatregelen op basis van wetenschappelijke inzichten. Ondanks de aanbevelingen van de Wereldgezondheidsorganisatie en uit wetenschappelijke onderzoeken is er in België nog altijd geen sprake van een nationaal alcoholbeleidsplan waarin deze maatregelen integraal zijn opgenomen. Maatregelen op het vlak van preventie, hulpverlening, prijs, aanbod en marketing zijn noodzakelijk om de schadelijke gevolgen van alcohol effectief te reduceren.
\end{abstract}

Trefwoorden alcohol · alcoholbeleid · België · gezondheidszorg · volksgezondheid

Abstract The omnipresence and social acceptance of alcohol in Belgium in many cases masks the harm-

R. Kramer $(\bowtie) \cdot T$. Decorte

Universiteit Gent, Gent, België

Ruben.Kramer@UGent.be

E. De Donder · M. Geirnaert

Vlaams expertisecentrum voor alcohol, illegale drugs, psychoactieve medicatie, gokken en gamen vzw, Brussel, België

M. de Duve

Univers Santé ASBL, Ottignies-Louvain-la-Neuve, België

T. Van Havere

Hogeschool Gent, Gent, België

F. Matthys

Hoge Gezondheidsraad, Brussel, België ful effects of alcohol. In order to reduce the negative consequences of harmful alcohol consumption, much research has been done in recent years into the effectiveness of possible policy measures. Despite the recommendations of these studies and of several health organizations, there is still no national alcohol policy plan in force in Belgium. Measures in the areas of prevention, care, price, supply and marketing are necessary to effectively reduce the harmful effects of alcohol.

Keywords Alcohol $\cdot$ Alcohol policy $\cdot$ Belgium $\cdot$ Health care $\cdot$ Public health

\section{De schadelijke gevolgen van alcohol}

Ondanks de algemene aanvaarding van alcohol in de samenleving mogen we de schade die door alcoholconsumptie wordt veroorzaakt niet onderschatten. In België ligt het percentage alcoholgebruikers $(77 \%)$ hoger dan het gemiddelde in Europa. Het problematische alcoholgebruik bij Belgen die het laatste jaar alcohol dronken steeg van $7 \%$ in 2001 naar $15 \%$ in 2018. Omgerekend naar de Belgische bevolking van 15 jaar en ouder ging dat in 2018 om 1.417 .250 personen. Daarnaast blijkt dat bij meer dan $10 \%$ van de Belgische bevolking ouder dan 15 jaar ooit sprake was van problematisch alcoholgebruik. In 2018 waren er in totaal 8.914 personen in behandeling voor alcoholmisbruik [1].

Wereldwijd is alcoholgebruik een belangrijke risicofactor voor diverse niet-overdraagbare ziekten (bijvoorbeeld hart- en vaatziekten, leveraandoeningen en verschillende kankervormen), lichamelijke letsels en vroegtijdig overlijden. Bij langdurig en overmatig gebruik kan alcohol schadelijke gevolgen hebben voor het welzijn en de gezondheid van de consument, voor de omgeving van de gebruiker (zoals 
alcoholgerelateerd geweld en seksueel misbruik) en voor de samenleving in het algemeen (bijvoorbeeld verminderde werkprestaties, verkeersongevallen of verstoring van de openbare orde) [2]. De aan alcohol gerelateerde schade wordt weerspiegeld in de hoge maatschappelijke kosten ten gevolge van alcoholgebruik, die in België volgens schattingen 2,1 miljard euro bedragen.

De mate waarin mensen voor de schadelijke gevolgen van alcohol vatbaar zijn, hangt samen met een complex geheel van factoren. Deze risicofactoren kunnen gerelateerd zijn aan de gebruiker (dat wil zeggen de leeftijd, het geslacht, het lichaamsgewicht, de fysieke of genetische kwetsbaarheid), de omgeving of de situatie waarin wordt gebruikt (bijvoorbeeld het besturen van een voertuig na alcoholconsumptie, of de blootstelling aan alcoholreclame, lage prijzen en een groot aanbod) en het product (dat wil zeggen de aard van het middel, de dosering en de gebruikswijze) [2]. Bovendien hangen veel van deze elementen onderling samen en versterken ze elkaar. Hierdoor lopen bepaalde groepen, zoals kinderen en jongvolwassenen, een verhoogd risico om geconfronteerd te worden met alcoholgerelateerde schade.

\section{Onderzoek naar effectieve beleidsmaatregelen}

Internationaal onderzoek wijst er veelvuldig op dat het invoeren van beleidsmaatregelen de schadelijke gevolgen van alcohol drastisch kan verlagen. Bij deze beleidsingrepen zijn tien doelgebieden te onderscheiden: leiderschap, bewustwording en betrokkenheid; reactie vanuit de gezondheidszorg; gemeenschappelijke actie; maatregelen en tegenmaatregelen rond rijden onder invloed; de beschikbaarheid; alcoholmarketing; het prijsbeleid; het beperken van de negatieve gevolgen van alcoholconsumptie en -vergiftiging; het beperken van de impact van illegaal en informeel geproduceerde alcohol op de volksgezondheid; en controle en toezicht. Recent Belgisch onderzoek en diverse gezondheidsorganisaties in België wijzen echter op de gebreken in het huidige nationale alcoholbeleid, die een effectieve aanpak van schadelijk alcoholgebruik in de weg staan[3-5]. Vooral de afwezigheid van een evidence-based integraal en geïntegreerd alcoholbeleid, bestaande uit de meest effectieve maatregelen om schadelijk alcoholgebruik te beperken en met als primair doel het beschermen van de volksgezondheid, maakt dat de Belgische bevolking nog onvoldoende beschermd wordt tegen de negatieve effecten van alcohol.

\section{De beleidssituatie in België}

Naar aanleiding van de aanbeveling van de Wereldgezondheidsorganisatie om een geïntegreerd alcoholbeleid uit te werken, is er in veel landen sprake van een uitgeschreven alcoholplan [6]. Sinds 2013 zijn er ook in België verschillende pogingen ondernomen om een omvattend nationaal alcoholplan te ontwikkelen met het oog op de preventie van schadelijk alcoholgebruik. Tot op heden is men er evenwel niet in geslaagd om een consensus te bereiken. Een belangrijke factor die aan het uitblijven van een alcoholplan ten grondslag ligt betreffen de botsende commerciële en volksgezondheidsbelangen. In België (en in Nederland) treden partijen uit de alcoholindustrie op als gesprekspartner bij het uitwerken van een nationaal preventieplan. De vrees voor economische gevolgen bij het invoeren van ingrijpende overheidsmaatregelen leidt ertoe dat vanuit de alcoholindustrie vooral wordt ingezet op eigen maatregelen binnen een zelfregulerend kader. Zodoende ontstaat een vreemde tegenstelling: de alcoholindustrie presenteert zich als 'onderdeel van de oplossing' voor een volksgezondheidsprobleem dat veroorzaakt wordt door de consumptie van hun producten.

Het is opvallend dat de interventies die door de industrie naar voren worden geschoven de aandacht verschuiven van (de schadelijkheid van) het product en de sociale omgeving naar de (individuele) verantwoordelijkheid van de consument, een tendens die zich ook lijkt te vertalen in het alcoholbeleid van de laatste jaren. Dit is onder meer zichtbaar in de eerste zinnen van het Convenant inzake Reclame voor en Marketing van Alcoholhoudende dranken (Alcoholconvenant): 'Alcoholverbruik is onlosmakelijk verbonden met onze samenleving. Het merendeel van de verbruikers gaat daar op een verantwoorde manier mee om'. Door te benadrukken dat de meeste consumenten op een verantwoorde manier met alcohol omgaan, stelt men impliciet dat schadelijk alcoholgebruik toe te schrijven is aan een kleine groep van 'onverantwoordelijke' gebruikers. Ook de - in het Alcoholconvenant verplicht gestelde - educatieve slogans 'Bier met liefde gebrouwen, drink je met verstand' en 'Ons vakmanschap drink je met verstand' verwijzen naar de verantwoordelijkheid van de consument en niet naar de (mogelijke) schadelijkheid van het product. Een dergelijke benadering negeert de multicausaliteit van de alcoholproblematiek en de complexe interactie tussen individuele kenmerken, productaspecten en omgevingsfactoren. De individuele keuzevrijheid van de consument wordt altijd mede beïnvloed en begrensd door elementen die losstaan van het individu. Factoren die een belangrijke invloed hebben op het koop- en consumptiegedrag van gebruikers zijn de prijs en de beschikbaarheid van alcoholhoudende producten, en de wijze waarop deze worden gepromoot. De relatief lage prijs en de grote beschikbaarheid van alcohol in België worden door verschillende gespecialiseerde preventiewerkers en onderwijsvertegenwoordigers in Vlaanderen en Wallonië echter als problematisch beschouwd. Een recent onderzoek naar de regulering van alcoholmarketing in België wijst bovendien op het problematische karakter van het huidige zelfregulerende kader rond alcoholmarketing [4]. 


\section{Behoefte aan een integraal alcoholbeleid}

De maatschappelijke kosten en de schadelijke gevolgen van alcohol voor de gebruiker, diens omgeving en de samenleving, maken dat er een behoefte is aan een gedegen en alomvattend alcoholbeleid. Een dergelijk beleid dient primair te vertrekken vanuit een gezondheidsperspectief en moet bestaan uit een geïntegreerd geheel van beleidsmaatregelen, dat is gestoeld op wetenschappelijke evidentie en de belangrijkste doelgebieden omvat. Gezien de multicausaliteit van de alcoholproblematiek volstaat het niet om in te zetten op afzonderlijke maatregelen. Een reeks op elkaar afgestemde interventies op het vlak van preventie, hulpverlening, prijs, aanbod en marketing is noodzakelijk om de schadelijke gevolgen van alcohol effectief te beperken. Op basis van de adviezen van de Wereldgezondheidsorganisatie en Belgische gezondheidsorganisaties, en recent nationaal onderzoek doen we een aantal gerichte aanbevelingen voor een nationaal alcoholbeleidsplan in België [6].

\section{Aanbevelingen}

Omdat de belangen van de alcoholindustrie (en verwante sectoren als retailers, de horeca en de reclamesector) conflicteren met die van de bescherming van de volksgezondheid, moet de medewerking van private partijen in het uitdenken en uitwerken van preventiecampagnes worden vermeden. De alcoholindustrie kan vanuit haar eigen verantwoordelijkheid en via haar distributiekanalen een bijdrage leveren door correcte en volledige informatie te verstrekken over de samenstelling van alcoholhoudende producten en de risico's van alcoholconsumptie.

Personen die ten gevolge van hun alcoholconsumptie problemen ervaren, moeten zo goed mogelijk worden geholpen door het aanbieden van goede ketenzorg. Vanuit een schadebeperkende benadering is het belangrijk dat eventuele problemen snel worden vastgesteld en dat de aangeboden hulp laagdrempelig en toegankelijk is. Bovendien moet er voldoende aanbod zijn, zodat wachtlijsten worden voorkomen.

Zoals hierboven aangegeven wordt het consumptiegedrag ook beïnvloed door omgevingsfactoren. Onderzoeken naar de effecten van maatregelen op het vlak van de prijs, het aanbod en alcoholreclame laten zien dat strikte regulering leidt tot een reductie van de schadelijke gevolgen van alcohol. Daarom is het aan te bevelen om de kostprijs van alcohol substantieel te verhogen. Dit is mogelijk door extra accijnzen te heffen op alcoholhoudende producten en door een minimum eenheidsprijs voor alcohol in te voeren.

Daarnaast dienen de beschikbaarheid en toegang tot alcohol te worden beperkt, bijvoorbeeld in de buurt van voetbalstadions, scholen of bij bepaalde evenementen. Lokale overheden kunnen interveniëren door het aantal locaties te beperken waar jongeren zonder toezicht alcohol kunnen aanschaffen en door strenger toezicht te houden op vergunningen.

Vanwege het effect dat alcoholmarketing heeft op de perceptie van alcohol, de leeftijd waarop men met drinken begint en de toename in schadelijk alcoholgebruik op de korte en lange termijn is het aan te bevelen om alcoholmarketing aan strenge restricties te onderwerpen. Ter bescherming van de volksgezondheid is een verbod op alcoholmarketing het meest aangewezen. Er moet werk worden gemaakt van een wettelijk regelgevend kader, waarin zo veel mogelijk wordt ingezet op het reduceren van het totale volume van alcoholmarketing en het verbieden van alcoholmarketingpraktijken die door risicogroepen (zoals minderjarigen) als aantrekkelijk worden ervaren. Daarbij is het raadzaam om de toegestane alcoholreclameboodschappen te beperken tot productgerelateerde informatie.

Er moet ingezet worden op betere voorlichting van (potentiële) gebruikers over de risico's van alcohol en het aanleren van vaardigheden die het kritisch denken over alcohol bevorderen. Het is aan te bevelen een multicomponentenaanpak te hanteren, bestaande uit selectieve preventiecampagnes die zich vooral richten op risicogroepen (bijvoorbeeld met leeftijdsbandjes op festivals) en op het sensibiliseren van ouders, op omgevingsinterventies (zoals educatie in reclamewijsheid) en op universele preventie op zowel lokaal niveau (bijvoorbeeld educatie over de schadelijke gevolgen van alcohol), als nationaal niveau (zoals ondersteunende mediacampagnes).

Willen de aanbevolen strategieën een optimaal effect hebben, dan is het noodzakelijk een maatschappelijk draagvlak te ontwikkelen en verkooppunten en mediakanalen regelmatig en systematisch te controleren. Daarom is het belangrijk om te blijven investeren in draagvlak voor restrictieve maatregelen. Initiatieven als 'Tournée Minérale', waarbij mensen in België worden uitgedaagd om gedurende de maand februari geen alcohol te drinken, kunnen helpen bij het vergroten van de bewustwording van de negatieve gevolgen van alcoholgebruik en daarmee het draagvlak voor restrictievere maatregelen.

\section{Conclusie}

Gezien de omvang en complexiteit van het alcoholprobleem (de maatschappelijke kosten en gezondheidsschade veroorzaakt door alcoholgebruik) en het ontbreken van een integraal en geïntegreerd alcoholbeleid is er dringend behoefte aan een coherent en integraal alcoholbeleid, met aandacht voor alle facetten van de problematiek, en vooral voor de elementen die leiden tot een reductie van schadelijk alcoholgebruik. Gezien de conflicterende belangen van de alcoholindustrie moet betrokkenheid van partijen uit deze sector worden vermeden bij het uitwerken van alcoholbeleid. De aanbevelingen die we in deze uiteenzetting hebben samengebracht, zijn gebaseerd op 
een reeks nationale en internationale onderzoeken, en kunnen worden gezien als de basisingrediënten voor een nationaal alcoholbeleidsplan in België.

Open Access This article is licensed under a Creative Commons Attribution 4.0 International License, which permits use, sharing, adaptation, distribution and reproduction in any medium or format, as long as you give appropriate credit to the original author(s) and the source, provide a link to the Creative Commons licence, and indicate if changes were made. The images or other third party material in this article are included in the article's Creative Commons licence, unless indicated otherwise in a credit line to the material. If material is not included in the article's Creative Commons licence and your intended use is not permitted by statutory regulation or exceeds the permitted use, you will need to obtain permission directly from the copyright holder. To view a copy of this licence, visit http://creativecommons.org/licenses/by/4.0/.

\section{Literatuur}

1. Antoine J. De TDI-registratie in België: jaarlijks rapport registratiejaar 2018. Brussel: Sciensano;2019.

2. WHO. Global status report on alcohol and health 2018. Genève: Wereldgezondheidsorganisatie; 2019.

3. HavereT van, Deforche B, Laenen Fvander, et al. The Law of 2009 concerning the selling and serving of alcohol toyouths: from state of the art to assessment (ALCOLAW). Brussels: Belgian Science Policy Office; 2018.

4. Decorte T, Kramer R, Vlaemynck M, et al. Assessment of alternative models for regulation of alcohol marketing in Belgium. Final report. Brussels: Belgian Science Policy Office; 2019.

5. Hoge Gezondheidsraad. Risico's van alcoholgebruik. Advies nr. 9438. Brussel: Hoge Gezondheidsraad; 2018.

6. WHO. Global strategy to reduce the harmful use of alcohol. Geneva:WHO;2010. 